\title{
Performance of two varieties of Nile tilapia farming in hapas and excavated ponds in Brazil
}

\author{
Desempenho de duas variedades de Tilápia-do-Nilo em hapas e \\ viveiros escavados no Brasil
}

\author{
Ed Christian Suzuki de Lima ${ }^{1 *}$; Julio Hermann Leonhardt ${ }^{2}$; Jayme Aparecido \\ Povh $^{3}$; Amauri Alcindo Alfieri ${ }^{4}$; Rodrigo Alejandro Arellano Otonel ${ }^{5}$; Angela Rocio \\ Poveda-Parra $^{6}$; Felipe Pinheiro de Souza ${ }^{1}$; Pâmela Juliana Furlan Murari ${ }^{1}$; \\ Cesar Toshio Facimoto ${ }^{1}$; Nelson Mauricio Lopera-Barrero ${ }^{7 *}$
}

\begin{abstract}
The great commercial potential of Nile tilapia is due to features such as its high production performance, its adaptability to different farming systems, and the development of genetic varieties with superior performance. Therefore, the objective of this study was to evaluate the performance of two varieties, GIFT (Genetic Improvement of Farmed Tilapia) and Supreme, grown in hapas in concrete tanks and grown in excavated ponds. Were used 200 and 1234 fingerlings of both varieties, GIFT and Supreme (average initial weight of $0.83 \mathrm{~g}$ ), for farming in hapas and ponds, respectively. Biometric measurements were taken at four farming stages (fingerling, juvenile, growth, and fattening). Were measured weight $(\mathrm{g})$, total length $(\mathrm{cm})$, standard length $(\mathrm{cm})$, trunk length $(\mathrm{cm})$, head length $(\mathrm{cm})$, head height $(\mathrm{cm})$, body height $(\mathrm{cm})$, weight gain $(\mathrm{g})$ and head/edible-part ratio. For all parameters and in all stages, superior results were observed for tilapia reared in excavated ponds. When the varieties were compared, GIFT had the best performance for most parameters in the fingerling stage, and for weight, total length, and body height in the juvenile stage. Both varieties grew better in excavated ponds. Moreover, GIFT showed higher growth than Supreme during all stages when grown in excavated ponds. Supreme showed higher growth than GIFT in hapas only in the growth stage. Thus, it is concluded that the rearing in excavated ponds provided better results, with superiority of the GIFT variety, which was more able to take advantage of the favorable conditions of this system.
\end{abstract}

Key words: Farming environment. Fish farming. Genotypes. Oreochromis niloticus. Strains.

\footnotetext{
1 Discentes, Programa de Pós-Graduação em Ciência Animal, Universidade Estadual de Londrina, UEL, Londrina, PR, Brasil. E-mail: edchris7@hotmail.com; felipeps1991@gmail.com; pamela.furlan@outlook.com; cesar.facimoto@hotmail.com

2 Prof. Dr., Departamento de Ciências Fisiológicas, UEL, Londrina, PR, Brasil. E-mail: leonhard@uel.br

3 Prof. Dr., Faculdade de Medicina Veterinária e Zootecnia, UFMS, Campo Grande, MS, Brasil. E-mail: jayme.peixegen@gmail. com

4 Prof. Dr., Departamento de Medicina Veterinária Preventiva, UEL, Londrina, PR, Brasil. E-mail: alfieri@uel.br

5 Prof. Dr., Centro Universitário Filadélfia, UNIFIL, Londrina, PR, Brasil. E-mail: otonel.rodrigo@gmail.com

${ }^{6}$ Dra ., Bolsista de Auxilio Técnico CNPq, Departamento de Zootecnia, UEL, Londrina, PR, Brasil. E-mail: angelapovedaparra@ hotmail.com

7 Prof. Dr., Departamento de Zootecnia, UEL, Londrina, PR, Brasil. E-mail: nmlopera@uel.br

* Author for correspondence
} 


\section{Resumo}

O grande potencial comercial da Tilápia-do-Nilo se deve a características como o alto desempenho produtivo, adaptabilidade a diferentes sistemas de criação e o desenvolvimento de variedades genéticas com desempenho superior. Portanto, o objetivo deste trabalho foi avaliar o desempenho de duas variedades, GIFT (Genetic Improvement of Farmed Tilapia) e Supreme, cultivadas em hapas em tanques de concreto e em viveiros escavados. Foram utilizados 200 e 1234 alevinos de ambas as variedades, GIFT e Supreme (peso médio inicial de $0,83 \mathrm{~g}$ ), para cultivo em hapas e viveiros escavados, respectivamente. As medidas biométricas foram realizadas em quatro etapas de cultivo (alevinos, juvenis, crescimento e engorda). Foram mensurados peso $(\mathrm{g})$, comprimento total $(\mathrm{cm})$, comprimento padrão $(\mathrm{cm})$, comprimento do tronco $(\mathrm{cm})$, comprimento da cabeça $(\mathrm{cm})$, altura da cabeça $(\mathrm{cm})$, altura corporal $(\mathrm{cm})$, ganho de peso (g) e cabeça proporção de parte comestível. Para todos os parâmetros e em todas as etapas, resultados superiores foram observados para tilápias criadas em viveiros escavados. Quando as variedades foram comparadas, a GIFT obteve o melhor desempenho para a maioria dos parâmetros no estágio de alevino, e para peso, comprimento total e altura do corpo no estágio juvenil. Ambas as variedades obtiveram maior crescimento em viveiros escavados. Além disso, o GIFT apresentou maior crescimento que a Supreme durante todos os estágios quando cultivado em viveiros escavados. A Supreme apresentou maior crescimento que o GIFT em hapas apenas no estágio de crescimento. Assim, conclui-se que a criação em viveiros escavados proporcionou melhores resultados, com superioridade da variedade GIFT, que foi mais capaz de aproveitar as condições favoráveis deste sistema.

Palavras-chave: Ambiente de cultivo. Genótipos. Linhagens. Oreochromis niloticus. Piscicultura.

\section{Introduction}

The Nile tilapia (Oreochromis niloticus) is one of the most distinctive species in fish farming, both in Brazil and globally. In 2012, it was the fourth most-produced species of fish in the world, with $3,197,330$ tons produced (FAO, 2014), and in 2011, the most-produced species in Brazil, with 253,824.1 tons produced (MPA, 2013). Owing to the favorable characteristics of the specie (rusticity, rapid growth, good feed conversion) (SANTOS, 2009), have been sought varieties that perform well and that adapt to production environments (NEVES et al., 2008).

Genetically improved varieties of Nile tilapia found in Brazil include GIFT (Genetically Improved Farmed Tilapia) and Supreme, also known as GST (Genomar Supreme Tilapia). Both varieties are the result of a project called GIFT (Genetic Improvement of Farmed Tilapias) that has been carried out from the late 1980s by World Fish Center (SANTOS, 2009; MASSAGO et al., 2010). The project's program used eight pure varieties, four domestic varieties from Asia and four wild varieties from Africa (MASSAGO et al., 2010). Supreme was introduced into Brazil in 2002 through Aquabel Fish Farming (ZIMMERMANN; FITZSIMMONS, 2004), and GIFT was introduced in 2005 by the State University of Maringa (UEM) (LUPCHINSKI JÚNIOR et al., 2008).

The productive behavior of these varieties needs to be evaluated in different existing farming systems, which have environmental variations that may affect performance. Temperature can affect performance by changing feed conversion ratio (EL-SAYED; KAWANNA, 2008), thereby compromising growth. Low levels of oxygen also change feed intake, thereby reducing growth rate and whole-body composition (TRAN-DUY et al., 2008). Natural food sources, especially phytoplanktons, are extremely important for tilapia, as they are an essential part of the diet of these fish in natural conditions (ENGDAW et al., 2013) and represent an important food source when present in the farming environment (ABOU et al., 2013). Furthermore, tilapia varieties may show differences in performance in different systems due to its genetic potential for growth under certain conditions that 
can be compromised under different conditions (CHARO-KARISA et al., 2006; SANTOS, 2009). Based on these facts, the study aimed to evaluate the influence of two farming systems on the performance parameters of the GIFT and Supreme varieties.

\section{Materials and Methods}

This research was approved by the Ethics Committee on Animal Use of the State University of Londrina (process no. 10375.2013.64).

Fish were cultivated in two different locations. The farming in hapas was conducted in Londrina city ( $23^{\circ} 18^{\prime}$ 'south latitude and $51^{\circ} 08^{\prime}$ longitude to west of Greenwich, at an average elevation of $519 \mathrm{~m}$ ), and the farming in excavated ponds in Florestópolis city $\left(22^{\circ} 50^{\prime}\right.$ south latitude and $51^{\circ} 23^{\prime}$ longitude to west of Greenwich, at an average altitude of 777 $\mathrm{m})$, both located in the northern region of the state of Paraná, Brazil. We used sexually inverted Nile tilapia fingerlings of GIFT (fifth generation of the breeding program conducted in State University of Maringá (UEM), Paraná, Brazil) and Supreme varieties, with an average initial weight of $0.83 \mathrm{~g}$ and an average length of 2 to $3 \mathrm{~cm}$. Initially, were cultivated 200 fingerlings of each variety in hapas (400 in total) and 1234 in excavated ponds (2468 in total). The experiment lasted 204 days, and was divided into four stages: fingerling, juvenile, growth, and fattening.

For hapa farming, the fish were placed in hapas, one for each variety, constructed with $1 \times 2 \mathrm{~mm}$ green shading meshes that were $1.4 \mathrm{~m}$ long, $0.6 \mathrm{~m}$ wide, and $0.8 \mathrm{~m}$ deep. The hapas for both varieties were assigned to the same concrete tank with constant replenishment of water (with total renewal every 290 minutes) from an artesian well. For this farming system, reclassification management was performed at the end of each stage. The objective of this procedure was to maintain the uniformity of the batches, based on the average weights obtained in mass collections. As a result of this, the number of fish at the beginning of each stage was, for the juvenile stage, 143 of both varieties; for the growth stage, 108 of both varieties; and for the fattening stage, 40 of GIFT and 60 of Supreme. In the early fattening stage, due to increases in the size of the fish, the GIFT fish were transferred to three hapas and those of Supreme to four, due to the different number of individuals of each variety, and hapas for both varieties were placed in the same concrete tank.

For farming in the excavated ponds, the fish were placed in $200 \mathrm{~m}^{2}(10 \mathrm{~m} \times 20 \mathrm{~m})$ ponds supplied with mine water. We used a separate pond for each variety, where it remained throughout the experimental period. A single reclassification was done at the end of the juvenile stage, as it was more difficult to implement in this system, were kept 600 individuals of each variety.

Both systems used the same feed management and the same specific feeds for each stage, which were, for the fingerling, juvenile, growth, and fattening stages, respectively: meal feed with 55\% $\mathrm{CP}$ (crude protein), extruded feed $1.0 \mathrm{~mm}$ with $45 \% \mathrm{CP}$, extruded feed $1.7 \mathrm{~mm}$ with $42 \% \mathrm{CP}$, and extruded feed $3.0 \mathrm{~mm}$ with $30 \% \mathrm{CP}$. Feed was provided ad libitum throughout the experimental period, the amount being divided into three daily feedings.

Biometric measurements were taken 23, 50, 113 , and $204 \mathrm{~d}$ after starting the experiment, once at the end of each farming stage. The day before measurements were taken, 10 fish were randomly selected from each variety in each farming system, to obtain a total of 40 fish per stage. The only exception was in the growth stage, when it was possible to collect only eight GIFT fish in hapas and nine in ponds. A total of 157 fish were collected during the trial period. On the days that the fish were collected, the following water quality parameters were analyzed: $\mathrm{pH}$, alkalinity $\left(\mathrm{mg} \mathrm{L}^{-1}\right)$, toxic ammonia $\left(\mathrm{mg} \mathrm{L} \mathrm{L}^{-1}\right.$ ), and transparency $(\mathrm{cm})$ using a Secchi disk. The parameters dissolved oxygen (DO; mg 
$\left.\mathrm{L}^{-1}\right)$ and temperature $\left({ }^{\circ} \mathrm{C}\right)$ were measured weekly. The DO levels and temperature were measured with the oximeter YSI 550A (YSI Inc., United States of America). The other parameters were measured using a colorimetric test kit (Fresh Water Producer's Kit) (Alfakit Ltd., Brazil).

Fish collected at each stage were taken to the Londrina city, where they were maintained for approximately 24 hours. They were then immobilized using a dose of $5 \mathrm{mg}$ of eugenol (clove oil) per liter of water. Then, using an electronic precision scale, a caliper rule, and an ichthyometer, were measured the following performance parameters: weight $(\mathrm{g})$, total length $(\mathrm{cm})$, standard length $(\mathrm{cm})$, trunk length $(\mathrm{cm})$, head length $(\mathrm{cm})$, head height $(\mathrm{cm})$ and body height $(\mathrm{cm})$. Were also evaluated the weight gain (g) and head/edible-part ratio, that is, the relation between head area (head length $x$ head height) and body area (trunk length $\mathrm{x}$ body height).

Results for the performance parameters were evaluated at each stage of farming (fingerling, juvenile, growth and fattening) separately, using a completely randomized design in a $2 \times 2$ factorial scheme - that is, two varieties (GIFT and Supreme) in two farming systems (hapas in concrete tanks and excavated ponds). The experimental unit consisted of one fish, with the use of 10 fish in each combination of variety and farming system, except for GIFT at growth stage, when were used eight fish in hapas and nine in ponds. Data were subject to analysis of variance ( $\alpha=0.05$ significance), and based on the observation of significant effect of factors or interaction between factors $(\mathrm{P}<0.05)$, means were compared using the Tukey's test $(\alpha$ $=0.05$ significance). All statistical analyses were performed using the statistical software R (R DEVELOPMENT CORE TEAM, 2011), version 3.1.3.

\section{Results}

Among the water quality parameters, for temperature and dissolved oxygen (DO), there were differences between the farming systems (Table 1). There were also differences for water transparency between the systems. In hapa farming, transparency was always at a maximum, that is, the bottom of the tank was visible, perhaps because the water did not come in contact with the ground, and in ponds farming, it oscillated from 40 to $80 \mathrm{~cm}$ in the GIFT pond and from 40 to $60 \mathrm{~cm}$ in the Supreme pond, indicating the presence of natural food in this system. For the other parameters, adequate values were found in all stages for the two farming systems. In relation to $\mathrm{pH}$ levels, it ranged between 6.2 and 6.4 in hapas, between 7.0 and 7.6 in the GIFT pond, and between 7.2 and 7.6 in the Supreme pond. Alkalinity $\left(\mathrm{mg} \mathrm{L}^{-1}\right)$ ranged between 30 and $35 \mathrm{mg}$ $\mathrm{L}^{-1}$ in hapas, between 25 and $30 \mathrm{mg} \mathrm{L}^{-1}$ in the GIFT pond, and $30 \mathrm{mg} \mathrm{L}^{-1}$ in all the cultivation stages in the Supreme pond. Toxic ammonia $\left(\mathrm{mg} \mathrm{L}^{-1}\right)$ was zero for both varieties in both farming systems, in all cultivation stages.

Table 1. Means and standard deviation for temperature and dissolved oxygen (DO) at fingerling, juvenile, growing and fattening stages for each farming system.

\begin{tabular}{ccccccc}
\hline & \multicolumn{3}{c}{ Temperature $\left(\mathrm{T}^{\circ} \mathrm{C}\right)$} & \multicolumn{3}{c}{ Dissolved oxigen $\left(\mathrm{mg} \mathrm{L}^{-1}\right)$} \\
Stage & $\mathrm{H}$ & GP & SP & H & GP & SP \\
\hline Fingerling & $23.6 \pm 0.66$ & $31.3 \pm 0.66$ & $29.7 \pm 1.23$ & $3.23 \pm 0.46$ & $6.94 \pm 0.18$ & $6.60 \pm 0.18$ \\
Juvenil & $22.8 \pm 0.60$ & $28.6 \pm 1.33$ & $27.8 \pm 1.22$ & $2.67 \pm 0.20$ & $6.85 \pm 0.30$ & $6.68 \pm 0.23$ \\
Growing & $22.5 \pm 0.93$ & $26.2 \pm 0.94$ & $26.2 \pm 1.15$ & $1.16 \pm 0.05$ & $8.71 \pm 0.18$ & $6.64 \pm 0.29$ \\
Fattening & $21.8 \pm 0.35$ & $19.1 \pm 1.41$ & $19.5 \pm 0.64$ & $4.20 \pm 0.42$ & $7.84 \pm 0.40$ & $6.84 \pm 0.13$ \\
\hline
\end{tabular}

$\mathrm{H}$, hapas for both varieties; GP, GIFT in excavated ponds; SP, Supreme in excavated ponds. 
The performance results are presented for each of the stages of farming (Tables 2, 3, 4 and 5). A system effect (without distinguishing between varieties) was observed at all stages for all evaluated parameters, except for the head/edible-part ratio in the fingerling stage. The presence or absence of a variety effect (without distinguishing between systems) and a system and variety interaction (combined effects of both factors) $(\mathrm{p}<0,05)$ varied among the stages and evaluated parameters.

Table 2. Means and standard deviation for performance parameters at Fingerling stage.

\begin{tabular}{|c|c|c|c|c|c|c|c|c|c|}
\hline \multicolumn{10}{|c|}{ Performance parameters at Fingerling stage } \\
\hline & W (g) & WG (g) & $\mathrm{TL}(\mathrm{cm})$ & $\mathrm{SL}(\mathrm{cm})$ & $\operatorname{TrL}(\mathrm{cm})$ & $\mathrm{HL}(\mathrm{cm})$ & $\mathrm{Hh}(\mathrm{cm})$ & $\mathrm{Bh}(\mathrm{cm})$ & $\mathrm{H} / \mathrm{EP}$ \\
\hline $\mathrm{GH}$ & $4.1 \pm 0.82^{\mathrm{Ba}}$ & $3.24 \pm 0.82^{\mathrm{Ba}}$ & $5.98 \pm 0.37$ & $4.75 \pm 0.31$ & $3.05 \pm 0.19$ & $1.70 \pm 0.17$ & $1.61 \pm 0.13$ & $1.85 \pm 0.16$ & $0.49 \pm 0.05$ \\
\hline $\mathrm{SH}$ & $3.7 \pm 0.62^{\mathrm{Ba}}$ & $2.87 \pm 0.62^{\mathrm{Ba}}$ & $5.90 \pm 0.45$ & $4.63 \pm 0.37$ & $2.95 \pm 0.30$ & $1.68 \pm 0.09$ & $1.47 \pm 0.15$ & $1.72 \pm 0.12$ & $0.49 \pm 0.04$ \\
\hline GV & $7.8 \pm 1.22 \mathrm{Aa}$ & $6.98 \pm 1.22^{\mathrm{Aa}}$ & $7.30 \pm 0.24$ & $5.91 \pm 0.25$ & $3.89 \pm 0.21$ & $2.02 \pm 0.08$ & $1.93 \pm 0.07$ & $2.27 \pm 0.12$ & $0.44 \pm 0.03$ \\
\hline SV & $5.8 \pm 1.30^{\mathrm{Ab}}$ & $4.92 \pm 1.30^{\mathrm{Ab}}$ & $6.86 \pm 0.47$ & $5.49 \pm 0.43$ & $3.54 \pm 0.32$ & $1.95 \pm 0.14$ & $1.76 \pm 0.18$ & $2.02 \pm 0.20$ & $0.48 \pm 0.05$ \\
\hline Effect & $* *$ & $* *$ & $* *$ & $* *$ & $* *$ & $*$ & $* *$ & $* *$ & - \\
\hline
\end{tabular}

GH - GIFT in hapas, SH - Supreme in hapas, GP - GIFT in ponds, SP - Supreme in ponds, W - weight, WG - weight gain, TL - total length, SL - standard length, TrL - trunk length, HL - head length, Hh - head height, Bh - body height, and H/EP - head/ediblepart ratio.

$*$ and $* *$ indicate a system effect and both system and variety effect $(\mathrm{P}<0.05)$, respectively. Means followed by different uppercase letters between systems in the same variety indicate significant differences $(\mathrm{P}<0.05)$. Means followed by different lowercase letters between varieties in the same system indicate significant differences $(\mathrm{P}<0.05)$.

Table 3. Means and standard deviation for performance parameters at Juvenile stage.

\begin{tabular}{lccccccccc}
\hline \multicolumn{7}{c}{ Performance parameters at Juvenile stage } \\
\hline & $\mathrm{W}(\mathrm{g})$ & $\mathrm{WG}(\mathrm{g})$ & $\mathrm{TL}(\mathrm{cm})$ & $\mathrm{SL}(\mathrm{cm})$ & $\mathrm{TrL}(\mathrm{cm})$ & $\mathrm{HL}(\mathrm{cm})$ & $\mathrm{Hh}(\mathrm{cm})$ & $\mathrm{Bh}(\mathrm{cm})$ & $\mathrm{H} / \mathrm{EP}$ \\
$\mathrm{GH}$ & $9.89 \pm 2.09^{\mathrm{Ba}}$ & $5.82 \pm 2.09$ & $8.01 \pm 0.54$ & $6.27 \pm 0.59$ & $4.20 \pm 0.47$ & $2.07 \pm 0.15$ & $2.07 \pm 0.12^{\mathrm{Ba}}$ & $2.60 \pm 0.18^{\mathrm{Ba}}$ & $0.40 \pm 0.04$ \\
$\mathrm{SH}$ & $9.66 \pm 2.15^{\mathrm{Ba}}$ & $5.96 \pm 2.15$ & $7.90 \pm 0.55$ & $6.23 \pm 0.56$ & $4.16 \pm 0.46$ & $2.07 \pm 0.14$ & $2.13 \pm 0.12^{\mathrm{Ba}}$ & $2.57 \pm 0.17^{\mathrm{Ba}}$ & $0.42 \pm 0.03$ \\
$\mathrm{GV}$ & $37.0 \pm 4.96^{\mathrm{Aa}}$ & $29.2 \pm 4.96$ & $12.3 \pm 0.60$ & $10.1 \pm 0.54$ & $6.95 \pm 0.45$ & $3.17 \pm 0.15$ & $3.30 \pm 0.21^{\mathrm{Aa}}$ & $4.02 \pm 0.19^{\mathrm{Aa}}$ & $0.38 \pm 0.03$ \\
$\mathrm{SV}$ & $32.1 \pm 3.97^{\mathrm{Ab}}$ & $26.3 \pm 3.97$ & $11.8 \pm 0.40$ & $9.72 \pm 0.41$ & $6.71 \pm 0.35$ & $3.01 \pm 0.07$ & $3.05 \pm 0.18^{\mathrm{Ab}}$ & $3.75 \pm 0.20^{\mathrm{Ab}}$ & $0.37 \pm 0.02$ \\
Effect & $* *$ & $*$ & $* *$ & $*$ & $*$ & $*$ & $*$ & $* *$ & $*$ \\
\hline
\end{tabular}

GH - GIFT in hapas, SH - Supreme in hapas, GP - GIFT in ponds, SP - Supreme in ponds, W - weight, WG - weight gain, TL - total length, SL - standard length, TrL - trunk length, HL - head length, Hh - head height, Bh - body height, and H/EP - head/ediblepart ratio.

* and ** indicate a system effect and both system and variety effect, respectively $(\mathrm{P}<0.05)$. Means followed by different uppercase letters between systems in the same variety indicate significant differences $(\mathrm{P}<0.05)$. Means followed by different lowercase letters between varieties in the same system indicate significant differences $(\mathrm{P}<0.05)$. 
Table 4. Means and standard deviation for performance parameters at Growth stage.

\begin{tabular}{|c|c|c|c|c|c|c|c|c|c|}
\hline \multicolumn{10}{|c|}{ Performance parameters at Growth stage } \\
\hline & W (g) & WG (g) & $\mathrm{TL}(\mathrm{cm})$ & $\mathrm{SL}(\mathrm{cm})$ & $\operatorname{TrL}(\mathrm{cm})$ & $\mathrm{HL}(\mathrm{cm})$ & $\mathrm{Hh}(\mathrm{cm})$ & $\mathrm{Bh}(\mathrm{cm})$ & $\mathrm{H} / \mathrm{E}$ \\
\hline GH & $38.0 \pm 7.26^{\mathrm{Ba}}$ & $28.1 \pm 7.26^{\mathrm{Ba}}$ & $12.2 \pm 0.95^{\mathrm{Bb}}$ & $9.75 \pm 0.73^{\mathrm{Bb}}$ & $6.75 \pm 0.50^{\mathrm{Bb}}$ & $3.00 \pm 0.32$ & $3.11 \pm 0.39^{\mathrm{Bb}}$ & $3.74 \pm 0.51^{\mathrm{Bb}}$ & $0.37 \pm 0.05$ \\
\hline $\mathrm{SH}$ & $53.6 \pm 9.80^{\mathrm{Ba}}$ & $44.0 \pm 9.80^{\mathrm{Ba}}$ & $13.9 \pm 0.78^{\mathrm{Ba}}$ & $11.0 \pm 0.59^{\mathrm{Ba}}$ & $7.56 \pm 0.44^{\mathrm{Ba}}$ & $3.41 \pm 0.18$ & $3.65 \pm 0.20^{\mathrm{Ba}}$ & $4.24 \pm 0.37 \mathrm{Ba}$ & $0.39 \pm 0.02$ \\
\hline GP & $213.3 \pm 29.1^{\mathrm{Aa}}$ & $176.4 \pm 29.1^{\mathrm{Aa}}$ & $21.4 \pm 1.10^{\mathrm{Aa}}$ & $17.5 \pm 0.81^{\mathrm{Aa}}$ & $12.8 \pm 0.52^{\mathrm{Aa}}$ & $4.69 \pm 0.40$ & $5.74 \pm 0.35^{\mathrm{Aa}}$ & $6.93 \pm 0.29^{\text {Аа }}$ & $0.30 \pm 0.03$ \\
\hline SP & $185.3 \pm 41.9^{\mathrm{Ab}}$ & $153.2 \pm 41.9^{\mathrm{Aa}}$ & $20.5 \pm 1.33^{\mathrm{Aa}}$ & $16.6 \pm 1.16^{\mathrm{Ab}}$ & $11.8 \pm 0.89^{\mathrm{Ab}}$ & $4.81 \pm 0.39$ & $5.22 \pm 0.44^{\mathrm{Ab}}$ & $6.33 \pm 0.56^{\mathrm{Ab}}$ & $0.34 \pm 0.03$ \\
\hline Effect & $*$ & $*$ & $*$ & $*$ & $*$ & $*$ & $*$ & $*$ & $* *$ \\
\hline
\end{tabular}

GH - GIFT in hapas, SH - Supreme in hapas, GP - GIFT in ponds, SP - Supreme in ponds, W - weight, WG - weight gain, TL - total length, SL - standard length, TrL - trunk length, HL - head length, Hh - head height, Bh - body height, and H/EP - head/ediblepart ratio.

$*$ and $* *$ indicate a system effect and both system and variety effect, respectively $(\mathrm{P}<0.05)$. Means followed by different uppercase letters between systems in the same variety indicate significant differences $(\mathrm{P}<0.05)$. Means followed by different lowercase letters between varieties in the same system indicate significant differences $(\mathrm{P}<0.05)$.

Table 5. Means and standard deviation for performance parameters at Fattening stage.

\begin{tabular}{cccccccccc}
\hline \multicolumn{8}{c}{ Performance parameters at Fattening stage } \\
\hline & $\mathrm{W}(\mathrm{g})$ & $\mathrm{WG}(\mathrm{g})$ & $\mathrm{TL}(\mathrm{cm})$ & $\mathrm{SL}(\mathrm{cm})$ & $\mathrm{TrL}(\mathrm{cm})$ & $\mathrm{HL}(\mathrm{cm})$ & Hh $(\mathrm{cm})$ & $\mathrm{Bh}(\mathrm{cm})$ & $\mathrm{H} / \mathrm{E}$ \\
$\mathrm{GH}$ & $170.2 \pm 42.3^{\mathrm{Ba}}$ & $132.2 \pm 42.3$ & $20.6 \pm 1.86$ & $16.4 \pm 1.39$ & $11.4 \pm 0.92$ & $5.11 \pm 0.56$ & $4.89 \pm 0.46$ & $6.05 \pm 0.58^{\mathrm{Ba}}$ & $0.36 \pm 0.02$ \\
$\mathrm{SH}$ & $193.0 \pm 34.0^{\mathrm{Ba}}$ & $139.4 \pm 34.0$ & $21.1 \pm 1.28$ & $17.1 \pm 1.05$ & $11.9 \pm 0.71$ & $5.21 \pm 0.38$ & $5.20 \pm 0.38$ & $6.48 \pm 0.48^{\mathrm{Ba}}$ & $0.35 \pm 0.04$ \\
$\mathrm{GP}$ & $456.5 \pm 83.7^{\mathrm{Aa}}$ & $243.2 \pm 83.7$ & $27.5 \pm 1.75$ & $22.8 \pm 1.47$ & $16.7 \pm 1.35$ & $6.17 \pm 0.26$ & $7.13 \pm 0.37$ & $8.56 \pm 0.61^{\mathrm{Aa}}$ & $0.31 \pm 0.03$ \\
$\mathrm{SP}$ & $381.6 \pm 85.8^{\mathrm{Ab}}$ & $196.4 \pm 85.8$ & $26.5 \pm 1.86$ & $21.9 \pm 1.50$ & $15.9 \pm 1.42$ & $5.99 \pm 0.19$ & $6.85 \pm 0.66$ & $7.90 \pm 0.75^{\mathrm{Ab}}$ & $0.33 \pm 0.03$ \\
Effect & $*$ & $*$ & $*$ & $*$ & $*$ & $*$ & $*$ & $*$ & $*$ \\
\hline
\end{tabular}

GH - GIFT in hapas, SH - Supreme in hapas, GP - GIFT in ponds, SP - Supreme in ponds, W - weight, WG - weight gain, TL - total length, SL - standard length, TrL - trunk length, HL - head length, Hh - head height, Bh - body height, and H/EP - head/ediblepart ratio.

* indicate a system effect $(\mathrm{P}<0.05)$. Means followed by different uppercase letters between systems in the same variety indicate significant differences $(\mathrm{P}<0.05)$. Means followed by different lowercase letters between varieties in the same system indicate significant differences $(\mathrm{P}<0.05)$.

In the fingerling stage (Table 2) was observed a farming system effect, with better performance in excavated ponds for all parameters except the head/edible-part ratio. A variety effect, with better performance by GIFT, was found for all parameters except head length and the head/edible-part ratio. In addition, for weight and weight gain, there was an interaction between variety and system, with superior results for both varieties when reared in excavated ponds and better performance of GIFT than of Supreme in this farming system.

In the juvenile stage (Table 3), a farming system effect was seen for all parameters, with the best performance in excavated ponds. A variety effect was observed for weight, total length, and body height, with better performance by GIFT. A varietyand-farming-system interaction was found for weight, head height, and body height, with better performance by both varieties in excavated ponds, with GIFT showing better results than Supreme in this system. Thus, it is possible that the variety effect for weight and body height was influenced by the superior performance of GIFT in excavated ponds.

In the growth stage (Table 4), a system effect was also observed for all parameters, with the best performance for fish reared in the excavated ponds. In contrast, a variety effect was observed only for 
the head/edible-part ratio, with higher values for Supreme. As for the interaction, there was again a better performance for both varieties when reared in excavated ponds, with GIFT showing higher values in this system for weight, standard length, trunk length, head height, and body height. In hapa farming, higher values were observed for Supreme for total length, standard length, trunk length, head height, and body height. For weight gain, the interaction was observed only at the system level, with both varieties showing superior performance in excavated ponds.

In the fattening stage (Table 5), as in earlier stages, a farming system effect was seen for all parameters, with better performance by fish reared in excavated ponds. No variety effect was found for any of the evaluated parameters. An interaction was found for weight and body height, with better performance for both varieties when reared in excavated ponds, and superior performance by GIFT in this farming system.

\section{Discussion}

For all evaluated parameters, the best performance was observed for fish cultivated in excavated ponds. Moreover, the results obtained for fish cultivated in hapas in concrete tanks were below commercially acceptable levels. This may be due to the difference in temperature and DO levels between systems, with values below those required for tilapia growth in hapa farming. For the Alkalinity, $\mathrm{pH}$, and ammonia parameters, values were within the recommended ranges (KUBTIZA, 2011; MORO et al., 2013) in both systems at all stages.

The thermal comfort range for tilapias is between 26 and $30{ }^{\circ} \mathrm{C}$ (KUBTIZA, 2011). In hapa farming, the temperature ranged from 21.8 to $23.6{ }^{\circ} \mathrm{C}$ during the trial period, which is below the minimum ideal temperature. In the excavated ponds the temperature was within the optimal range at all stages in both systems, except in the fattening stage for both GIFT and Supreme, when temperatures were, respectively, 19.1 and $19.5^{\circ} \mathrm{C}$, since this analysis was done during the winter (in the month of august). An influence of low temperature on Oreochromis niloticus performance has been observed in some studies (EL-SAYED; KAWANNA, 2008; SANTOS et al., 2013) and is therefore a possible cause of the poor performance of fish reared in hapas. Moreover, the temperature in the excavated ponds may also have restricted growth, as was evidenced by the temperature of approximately $19^{\circ} \mathrm{C}$ for both varieties in the fattening stage. Further, since all parameters were higher for fish reared in ponds than those reared in hapa farming, it is possible that the performance would have been even higher if temperatures had been suitable throughout the experimental period.

As mentioned, the low DO levels in hapa farming may also have affected the results, as the negative effect of this factor has been demonstrated by other studies. The DO levels in hapa farming throughout the experimental period were below or close to the minimum of $3 \mathrm{mg} \mathrm{L}^{-1}$ required for tropical fish (MORO et al., 2013). The low values of this factor can reduce the feed intake (TRAN-DUY et al., 2008) and change the directed energy to respiratory activity (FERNANDES; RANTIN, 1994), thereby, compromising performance. Therefore, the low DO levels found in hapa farming in the present study possibly had the same effects as those presented by these other studies, and may be responsible for the lower performance of fish reared in this system.

Additionally, in relation to water transparency, values vary according to the presence of suspended solids, organic matter, and microorganisms (MORO et al., 2013), and, as expected, differences were observed between the systems. The availability of natural food in the farming of excavated ponds, as indicated by the water transparency results, may have positively influenced the performance of fish reared in this system. Abou et al. (2013) found higher final mean weights for $O$. niloticus reared in excavated ponds than for those reared in concrete tanks when both groups were fed the same diets, 
possibly due to the nutritional composition of the natural food. Therefore, it is possible that the presence of natural food in this study, due to its nutritional characteristics, increased fish growth in excavated ponds.

A variety effect was observed at the fingerling stage, with better performance by the GIFT variety on most parameters, demonstrating the higher growth potential of GIFT in both farming systems. In the juvenile stage, the higher growth was significant only for weight, total length, and body height. In the following stages, there was no variety effect for any of the evaluated parameters, except for the smaller head/edible-part ratio for GIFT in the growth stage, indicating a smaller head area in relation to the edible body area, and thus a greater amount of meat. Thus, the better performance of GIFT in the fingerling and juvenile stage may have been influenced by its greater growth potential in pond farming. The interaction between variety and farming system, although present in the fingerling and juvenile stages, was more evident in the subsequent stages. In general, in the growing stage, GIFT had higher growth in excavated ponds and Supreme in hapas, suggesting that at this stage the varieties showed better adaptation to the respective systems. In the fattening stage, GIFT had higher weight and body height, confirming its higher growth potential in this system. Throughout the stages, the only parameter that was not affected by variety or its interaction with the farming system was head length. This may have occurred because increased head length may reduce production, so it probably was not the focus of the breeding program for either evaluated variety.

As mentioned, during the farming period, GIFT performed better in excavated ponds, with greater weight and body height in all stages. These metrics are good indicators of growth performance, since the weight obtained by GIFT in this system was the closest to commercial suitable values of all the weights recorded for the different variety and evaluated system combinations. In addition, body height is positively correlated with fillet yield, confirming the higher potential of GIFT in excavated ponds. Moreover, greater values for weight gain in the fingerling stage, for head height in the juvenile and growth stages, and for standard length and trunk length in the growth stage, indicate the potential of additional increased body growth of GIFT in excavated ponds. These results demonstrate the potentially superior ability of GIFT to take advantage of conditions present in this farming system, in relation to those of Supreme.

In the GIFT project the selection for body weight at harvest was carried out in excavated ponds, since its focus was to provide increased production in family scale pond farms and backyard ponds (BENTSEN et al., 2012), therefore, the GIFT variety should demonstrate adequate results when reared in farming environments with conditions similar to that system. Supreme and GIFT were developed from the same project, however, started to be developed independently since 1999 (MASSAGO et al., 2010), thereby, it is possible that these performance differences are related to the selection process these varieties experienced after their separation.

This adaptability might be related to better environmental conditions, and not to the system as a whole. In concurrence with this belief, Santos (2009) found that GIFT had a higher heritability for body weight in net cages than in excavated ponds. According to the author, this may be due to the better conditions in this system, in particular the better water quality and the higher protein level in the diet, suggesting that the expression of the genetic potential for this feature in this variety is influenced by these factors. Possibly, similar situation occurred in the present study, since, as mentioned, farming in ponds provided better environmental conditions than hapa farming.

As for the restrictive factors, GIFT may have had a greater tolerance to low temperatures than Supreme when cultivated in ponds in the fattening stage. At this stage, which was the longest (91 days), GIFT had a greater weight and body height, demonstrating its greater growth potential even at an observed 
approximate temperature of $19^{\circ} \mathrm{C}$ in the pond for both varieties. Therefore, low temperatures may not have been the only factor limiting GIFT growth in hapa farming; it is likely that this was because of the interaction of temperature with low oxygen levels, or even that low temperature had no effect.

In hapas in the growth stage, the better results for Supreme may have occurred due to its greater tolerance to the restrictive factors in this farming system. Since low temperatures may not have influenced the performance difference between varieties in hapas, the better growth demonstrated by Supreme may have been caused by its higher tolerance to low levels of DO. Charo-Karisa et al. (2006) found differences in the performance of $O$. niloticus cultivated in two different ponds, which may be a result of differences in DO levels. Due to the difference in performance of the same families in the two ponds, the authors suggested the presence of genotypes with higher tolerance to DO restriction. Therefore, it is likely that the Supreme fish used in this study had this feature, which caused their better growth in hapas. However, the higher growth of Supreme in hapas in the growth stage was not important to production, since this interaction did not persist to the end of the experimental period. Moreover, the final weight of fish reared in hapas was below the market weight, making the best performance of Supreme irrelevant from the perspective of commercial production, at least when considering farming for a duration similar to that of this study.

\section{Conclusions}

Thus, were concluded that farming in excavated ponds resulted in better performance because it provided more favorable conditions for the development of Nile tilapia, with GIFT variety performing better than Supreme variety in this system. In contrast, in hapa farming, Supreme had higher growth, although this was not relevant in terms of commercial production.

\section{Acknowledgements}

The authors would like to thank the 'CAPES', $\mathrm{CNPq}$ and the "Programa de Pós Graduação em Ciência Animal” (State University of Londrina).

\section{References}

ABOU, Y.; AINA, M. P.; FIOGBÉ, E. D.; MICHA, J. Growth and fatty acid composition of Nile tilapia Oreochromis niloticus L. fed Azolla-diets, in tanks and in earthen ponds: a comparative study. Natural Science, Oxford, v. 5, n. 1, p. 77-83, 2013.

BENTSEN, H. B.; GJERDE, B.; NGUYEN, N. H.; RYE, M.; PONZONI, R. W.; PALADA DE VERA, M. S.; BOLIVAR, H. L.; VELASCO, R. R.; DANTING, J. C.; DIONISIO, E. E.; LANGALONG, F. M.; REYES, R. A.; ABELLA, T. A.; TAYAMEN, M. M.; EKNATH, A. E. Genetic improvement of farmed tilapias: Genetic parameters for body weight at harvest in Nile tilapia (Oreochromis niloticus) during five generations of testing in multiple environments. Aquaculture, Amsterdam, v. 338-341, p. 56-65, 2012.

CHARO-KARISA, H.; KOMEN, H.; REYNOLDS, S.; REZK, M. A.; PONZONI, R. W.; BOVENHUIS, H. Genetic and environmental factors affecting growth of Nile tilapia (Oreochromis niloticus) juveniles: modelling spatial correlations between hapas. Aquaculture, Amsterdam, v. 255, n. 2-4, p. 586-596, 2006.

EL-SAYED, A. M.; KAWANNA, M. Optimum water temperature boosts the growth performance of Nile tilapia (Oreochromis niloticus) fry reared in a recycling system. Aquaculture Research, Oxford, v. 39, n. 6, p. 670-672, 2008.

ENGDAW, F.; DADEBO, E.; NAGAPPAN, R. Morphometric relationships and feeding habits of Nile Tilapia Oreochromis niloticus (L.) (Pisces: Cichlidae) from Lake Koka, Ethiopia. International Journal of Fisheries and Aquatic Sciences, Faisalabad, v. 2, n. 4, p. 65-71, 2013.

FERNANDES, M. N.; RANTIN, F. T. Relationships between oxygen availability and metabolic cost of breathing in Nile tilapia (Oreochromis niloticus): aquacultural consequences. Aquaculture, Amsterdam, v. 127, n. 4, p. 339-346, 1994.

FOOD AND AGRICULTURE ORGANIZATION OF THE UNITED NATIONS - FAO. FAO yearbook. Fishery and Aquaculture Statistics, 2012. Roma: FAO, 2014. 105 p. 
KUBTIZA, F. Tilápia: tecnologia e planejamento na produção comercial. 2. ed. Jundiaí: F. Kubtiza, 2011. 316 p.

LUPCHINSKI JÚNIOR, E.; VARGAS, L.; POVH, J. A.; RIBEIRO, R. P.; MANGOLIN, C. A.; LOPERA BARRERO, N. M. Avaliação da variabilidade das gerações G0 e F1 da linhagem GIFT de tilápia do Nilo (Oreochromis niloticus) por RAPD. Acta Scientiarum. Animal Sciences, Maringá, v. 30, n. 2, p. 233-240, 2008.

MASSAGO, H.; CASTAGNOLLI, N.; MALHEIROS, E. B.; KOBERSTEIN, T. C. R. D.; SANTOS, M. A.; RIBEIRO, R. P. Crescimento de quatro linhagens de tilápia Oreochromis niloticus. Revista Acadêmica: Ciências Agrárias Ambientais, São José dos Pinhais, v. 8, n. 4, p. 397-403, 2010.

MINISTÉRIO DA PESCA E AQUICULTURA - MPA. Boletim Estatístico da Pesca e Aquicultura 2011. Brasília: MPA, 2013. 60 p.

MORO, G. V.; TORATI, L. S.; LUIZ, D. B.; MATOS, F. T. Monitoramento e manejo da qualidade da água em pisciculturas. In: RODRIGUES, A. P. O.; LIMA, A. F.; ALVES, A. L.; ROSA, D. K.; TORATI, L. S.; SANTOS, V. R. V. Piscicultura de água doce: multiplicando conhecimentos. Brasília: EMBRAPA, 2013. p. 141-169.

NEVES, P. R.; RIBEIRO, R. P.; VARGAS, L.; NATALI, M. R. M.; MAEHANA, K. R.; MARENGONI, N. G. Evaluation of the performance of two strains of
Nile Tilapia (Oreochromis Niloticus) in mixed raising systems. Brazilian Archives of Biology and Technology, Curitiba, v. 51, n. 3, p. 531-538, 2008.

R DEVELOPMENT CORE TEAM - R: A language and environment for statistical computing. Vienna: The $\mathrm{R}$ Foundation for Statistical Computing, 2011. Available at: $<$ http://www.R-project.org/>. Accessed at: 3 may 2018.

SANTOS, A. I. Interação genótipo-ambiente $e$ estimativas de parâmetros genéticos em tilápias. 2009. Tese (Doutorado em Zootecnia) - Centro de Ciências Agrárias, Universidade Estadual de Maringá, Maringá.

SANTOS, V. B.; MARECO, E. A.; DAL PAI SILVA, M. Growth curves of Nile tilapia (Oreochromis niloticus) strains cultivated at different temperatures. Acta Scientiarum. Animal Sciences, Maringá, v. 35, n. 3, p. 235-242, 2013.

TRAN-DUY, A.; SCHRAMA, J. W.; VAN DAM, A. A.; VERRETH, J. A. J. Effects of oxygen concentration and body weight on maximum feed intake, growth and hematological parameters of Nile tilapia, Oreochromis niloticus. Aquaculture, Amsterdam, v. 275, n. 1-4, p. 152$162,2008$.

ZIMMERMANN, S.; FITZSIMMONS, K. Tilapicultura intensiva. In: CYRINO J. E. P.; URBINATI, E. C.; FRACALOSSI, D. M.; GASTAGNOLLI, N. Tópicos especiais em piscicultura de água doce tropical intensiva São Paulo: TecArt, 2004. p. 239-266. 